\title{
ASSESSMENT OF CLINICAL PROFILE AND LABORATORY PARAMETERS IN PATIENTS WITH SUSPECTED MENINGITIS AND THEIR OUTCOME AT A TERTIARY CENTRE, BAREILLY U. P.
}

Nisha Pandey ${ }^{1}$, Ajay Pratap ${ }^{2}$

\section{HOW TO CITE THIS ARTICLE:}

Nisha Pandey, Ajay Pratap. "Assessment of Clinical Profile and Laboratory Parameters in Patients with Suspected Meningitis and their Outcome at a Tertiary Centre, Bareilly U. P.". Journal of Evolution of Medical and Dental Sciences 2015; Vol. 4, Issue 45, June 04; Page: 7816-7822, DOI: 10.14260/jemds/2015/1137

ABSTRACT: A prospective study was carried out in department of Pediatrics between January 2013June 2014. All patients admitted as suspected meningitis meeting our inclusion criteria were followed till discharge. Clinical profile, laboratory parameters and outcome at discharge were assessed. Total 95 patients were enrolled in the study. Out of which 73 patients were followed up till discharge meeting our inclusion criteria. Forty seven (64.38\%) were diagnosed as Tubercular meningitis, $22(30.13 \%)$ as pyogenic meningitis and $4(5.47 \%)$ as aseptic meningitis. CSF ADA, CSF glucose and CSF WBC count were significant in diagnosis of meningitis. Early detection and prompt therapy are most important factors in prognosis of meningitis.

KEYWORDS: Bacterial, tubercular, Viral meningitis, C S F ADA.

INTRODUCTION: Meningitis is inflammation of membranes which surrounds brain and spinal cord. It results from the lymphohaematogenous spread of micro-organism from distant site of primary infection. It is the major cause of morbidity and mortality in infants and children below 5 years.(1) The disease is caused mainly by bacterial or viral pathogens.(2)

Tuberculosis is also one of important cause of meningitis in children especially in developing countries. More than 2/3 cases of meningitis occurs in less than 5 years of life due to decreased immunity and high vascularity of the brain.(3) The clinical presentation is vague due to immaturity of CNS in infants and children. B The incidence of tuberculosis is on the increase worldwide. ${ }^{(4)}$ Between 1 to $2 \%$ of children with untreated extracranial TB develop tubercular meningitis (TBM).(5)

AIM AND OBJECTIVES: To Study the clinical profile, cyto-pathological parameters of cerebrospinal fluid and outcome of the children admitted with suspected meningitis.

\section{MATERIAL AND METHODS:}

Study Design: Prospective study.

Study Period: January 2013 to June 2014.

Inclusion Criteria: Patients of age group 6 months to 14 years who were suspected to be a case of meningitis on the basis of history and clinical examination and CSF parameters were studied.

Suspected cases of meningitis were defined as per WHO. All patients with clinical symptoms of meningitis, example fever, headache, neck stiffness, vomiting and change in mental status and meningeal signs, bulging fontanel, papilledema, cranial nerve palsy and motor weakness of the limbs. 


\section{EXCLUSION CRITERIA:}

1. Old cases of meningitis treated outside the hospital before referral.

2. Children suffering from chronic illness or malignancy.

3. Children on immunosuppressive drugs.

Lumbar punctures were performed and fresh CSF samples were collected from all patients. CSF samples were subjected to analysis of protein, glucose, total and differential leucocyte count, gram staining, acid fast staining and culture sensitivity.

Consent was taken from guardians of patients and approval for study was taken from ethical committee of institute.

\begin{tabular}{|c|c|c|c|}
\hline Findings & $\begin{array}{l}\text { Pyogenic } \\
\text { Meningitis }\end{array}$ & $\begin{array}{l}\text { Tubercular } \\
\text { Meningitis }\end{array}$ & Aseptic Meningitis \\
\hline Gross appearance & Turbid & $\begin{array}{l}\text { Clear or straw } \\
\text { coloured, cob web } \\
\text { on standing. }\end{array}$ & Clear \\
\hline Proteins & $\begin{array}{l}\text { Usually } \\
100-500 \mathrm{mg} / \mathrm{dl}\end{array}$ & $\begin{array}{l}\text { Elevated, upto } \\
300 \mathrm{mg} / \mathrm{dl} \text {,may be } \\
>500 \mathrm{mg} / \mathrm{dl}\end{array}$ & Normal \\
\hline Sugar & $\begin{array}{l}\text { Reduced,usually } \\
<40 \mathrm{mg} / \text { dl }\end{array}$ & $\begin{array}{l}\text { Reduced,usually } \\
<50 \mathrm{mg} / \mathrm{dl}\end{array}$ & Normal \\
\hline Cells & $\begin{array}{l}100- \\
10,000, \text { usually } \\
300-2000, \text { mainly } \\
\text { polymorphs }\end{array}$ & $\begin{array}{l}10-500 / \mathrm{mm}^{3},(25- \\
100) \text { predominantly } \\
\text { Iymphocytes }\end{array}$ & $\begin{array}{l}\text { Upto } \\
100 / \mathrm{mm} 3, \text { Mononu } \\
\text { clear } \\
\text { predominance. }\end{array}$ \\
\hline culture & $\begin{array}{l}\text { Pyogenic } \\
\text { organisms may be } \\
\text { isolated. }\end{array}$ & $\begin{array}{l}\text { Difficult to isolate } \\
\text { tubercular bacilli. }\end{array}$ & Not helpful \\
\hline
\end{tabular}

\section{Table 1}

Vaccination history and history of close contact with a known patient suffering from pulmonary tuberculosis was elicited.

Chest radiograph and Monteux skin test were carried out for all patients. Nutritional assessment was done in all patients according to WHO classification. All patients received treatment as per standard protocol of etiological diagnosis. The mortality and morbidity of all cases were assessed at the time of discharge.

RESULTS: Total 95 Patients were enrolled in study. Out of 95 patients 22 were excluded meeting our exclusion criteria. 13 patients had already received treatment for meningitis from outside and later diagnosed as partially treated septic meningitis, 5 patients were already receiving antitubercular treatment and had neurological sequelae, 2 patients had postencephalitic sequelae and 2 patients were diagnosed as acute leukemia. Finally 73 patients met our inclusion criteria. Out of which 47 were diagnosed as tubercular meningitis, 22 as septic meningitis and 4 as aseptic meningitis.

Most of patients with tubercular meningitis were between 9 months to 4 yrs. (Mean age-2.4 yrs), those with bacterial meningitis ranged from 6 months to 3 yrs. (Mean age-1.9 yrs) and patients of aseptic meningitis ranged from 2 yrs. to 8yrs. (Mean age-5.5 yrs.) . At our institute males presenting with meningitis were more than females. 


\begin{tabular}{|c|c|c|c|}
\hline Diseases & $\begin{array}{c}\text { Tubercular Meningitis } \\
(\mathbf{n = 4 7 )}\end{array}$ & $\begin{array}{c}\text { Bacterial Meningitis } \\
(\mathbf{n = 2 2})\end{array}$ & $\begin{array}{c}\text { Viral Meningitis } \\
(\mathbf{n = 4 )}\end{array}$ \\
\hline Male & $26(55.3 \%)$ & $18(81.8 \%)$ & $3(75 \%)$ \\
\hline Female & $21(44.68 \%)$ & $4(18.18 \%)$ & $1(25 \%)$ \\
\hline Age(mean) & $2.4 y e a r s$ & 1.9 years & 5.5 years \\
\hline \multicolumn{3}{|c|}{ Table 2: Age and Sex Distribution } \\
\hline
\end{tabular}

At our institute fever followed by altered mental status, seizures, vomiting and headache were most common presenting complaints.

Neurological deficit was found in total of 22 patients at presentation. It was more common in cases with bacterial meningitis (36.3\%) compared to TBM $(29.78 \%)$. Whereas none of the cases with aseptic meningitis had neurologic deficit.

In our study history of contact with a known case of tuberculosis, usually a household contact, provided supportive evidence to the clinical diagnosis of TBM.

Tuberculin test is a useful tool for diagnosis of tuberculosis in children. We found positive tuberculin reaction in $20 \%$ cases of TBM. However, its diagnostic value is limited in the more severe forms of tuberculosis, like TBM and MTB.

In our study only $6(12.7 \%)$ cases of TBM had shown positive AFB from gastric aspirate showing poor yield of sample.

\begin{tabular}{|c|c|c|c|}
\hline & $\begin{array}{c}\text { TUBERCULAR } \\
\text { MENINGITIS (N=47) }\end{array}$ & $\begin{array}{c}\text { BACTERIAL } \\
\text { MENINGITIS (N = 22) }\end{array}$ & $\begin{array}{c}\text { VIRAL MENINGITIS } \\
\text { ( N=4) }\end{array}$ \\
\hline fever & $40(85 \%)$ & $18(81.8 \%)$ & $3(75 \%)$ \\
\hline Altered sensorium & $31(65.9 \%)$ & $14(63.6 \%)$ & $1(25 \%)$ \\
\hline seizure & $37(78.7 \%)$ & $18(81.8 \%)$ & 0 \\
\hline vomiting & $35(74.4 \%)$ & $14(63.6 \%)$ & $4(100 \%)$ \\
\hline headache & $35(74.4 \%)$ & $16(72.7 \%)$ & 0 \\
\hline Neurological deficit & $14(29.78 \%)$ & $8(36.3 \%)$ & 0 \\
\hline Papilloedema & $10(21.2 \%)$ & $14(63.6 \%)$ & 0 \\
\hline BCG scar & $11(23.4 \%)$ & $7(31.8 \%)$ & 0 \\
\hline Undernourished & $19(40.4 \%)$ & $12(54.5 \%)$ & 0 \\
\hline Tuberculin positive & $15(31.9 \%)$ & 0 & 0 \\
\hline h/o contact with TB & $14(29.78 \%)$ & 0 & 0 \\
\hline Positive gastric & $6(12.7 \%)$ & 0 & \\
aspirate for AFB & \multicolumn{4}{|c|}{ Table 3: Comparative data of clinical features and } \\
\hline \multicolumn{5}{|c|}{ examination findings in suspected meningitis } \\
\hline
\end{tabular}

Our patients showed significant CSF leucocytosis with neutrophilic predominance (90\%) and high CSF protein ( $>50 \mathrm{mg} / \mathrm{dl}$ ) $(72.7 \%)$ in bacterial meningitis compared to the nonbacterial meningitis group. ALL patients with TBM had greater than $90 \%$ lymphocytes in CSF.CSF glucose concentration is decreased $<45 \mathrm{mg} / \mathrm{dl}$ in $72.7 \%$ of patients with bacterial meningitis and significantly above $45 \mathrm{mg} / \mathrm{dl}$ in all patients of the aseptic meningitis. In our study Low CSF glucose and elevated protein are other characteristic abnormalities seen in TBM. 


\section{ORIGINAL ARTICLE}

Newer diagnostic techniques have been introduced as CSF ADA levels for TBM. In our study CSF ADA was found to be $>5$ IU/L in $45(96 \%)$ of TBM cases.

We did CT scanning in $\mathbf{4 0}$ patients, as others either refused scanning or could not afford it:

- Basal enhancement in $25 \%$.

- Hydrocephalus in $25 \%$.

- Infarcts in 5.0\%.

- Cerebral oedema in $8.0 \%$ and more than 1 finding in $32.0 \%$ of the patients.

- Normal study was in $29 \%$.

\begin{tabular}{|c|c|c|c|}
\hline & $\begin{array}{c}\text { TUBERCULAR } \\
(\mathrm{N}=47)(\%)\end{array}$ & $\begin{array}{l}\text { BACTERIAL } \\
(\mathrm{N}=22)(\%)\end{array}$ & $\begin{array}{c}\text { VIRAL } \\
(\mathrm{N}=4)(\%)\end{array}$ \\
\hline CSF leucocyte count $(>501-1000 / \mu \mathrm{l})$ & $39(82.9)$ & $20(90.9)$ & 0 \\
\hline CSF leucocyte count $(101-500 / \mu \mathrm{l})$ & $8(17.02)$ & $2(9.09)$ & 0 \\
\hline CSF leucocyte count $(100 / \mu \mathrm{l})$ & 0 & 0 & $4(100)$ \\
\hline CSF lymphocyte (>90\%) & $47(100)$ & 0) & 0 \\
\hline CSF neutophil $(>90 \%)$ & 0 & $22(100)$ & 0 \\
\hline CSF PROTEIN $(<100 \mathrm{mg} / \mathrm{dl})$ & 0 & 0 & 4 \\
\hline CSF PROTEIN $(100-250 \mathrm{mg} / \mathrm{dl})$ & $7(14.8)$ & $1(4.5)$ & 0 \\
\hline CSF PROTEIN (250-500 mg/dl) & $15(31.9)$ & $5(22.7)$ & 0 \\
\hline CSF PROTEIN (>500 mg/dl) & $25(53.1)$ & $16(72.7)$ & \\
\hline CSF GLUCOSE $(<45 \mathrm{mg} / \mathrm{dl})$ & $44(93.6)$ & $16(72.7)$ & 0 \\
\hline CSF ADA $(>5$ IU $)$ & $45(95.74)$ & 0 & 0 \\
\hline CSF culture & 0 & 0 & 0 \\
\hline
\end{tabular}

\begin{tabular}{|c|c|c|c|}
\hline & Improved & Neurological Sequlae & Deaths \\
\hline T. B. M. (n=47) & 33 & 14 & 2 \\
\hline Bacterial Meningitis (n= 22) & 17 & 8 & 2 \\
\hline Aseptic Meningitis (n = 4) & 4 & 0 & 0 \\
\hline \multicolumn{2}{|r}{ Table 5: Outcome at Discharge } \\
\hline
\end{tabular}

DISCUSSION: Our study showed that the frequency of bacterial meningitis is more prevalent in age group of 6 months to 3 years. Bacterial meningitis is the major cause of morbidity in children below the age of 5 years.[1]

In our study TBM was found to be in the age group of 9 months to 4 years. Study done by Wilson et al found the greatest frequency of TBM cases in children between the ages 1 to 9 years.(4)

At our institute fever followed by altered mental status, seizures, vomiting and headache were most common presenting complaints. Similar study done by Vaswani et al showed that fever, headache, vomiting and altered mental status were the main complaints of the patients who were diagnosed to be meningitis.(5)

BCG vaccination, even though influenced by nutritional status, state of allergic reaction and time elapsed is expected to give protection against tuberculosis, especially of the central nervous system. 
In our study $23.4 \%$ of the cases of TBM were BCG vaccinated. However, TBM has been reported in $11 \%$ to $35 \%$ of BCG vaccinated children.(6)

A positive tuberculin reaction was observed in $75 \%$ cases of TBM in one of the studies. ${ }^{(7)}$ even though others have reported a negative result in a large proportion of cases.(8)

In our study CSF culture did not grow any bacteria and none of the cases had isolated M. TB showing a low bacterial yield. Elerie J. Williams et al also could recover only 9 bacteria from culture of 199 CSF sample. (9) The positivity of CSF cultures in TBM has been reported to vary from $8 \%$ to $58 \%$ by several workers in India.(10)

Our patients showed significant CSF leucocytosis with neutrophilic predominance (90\%) and high CSF protein ( $>50 \mathrm{mg} / \mathrm{dl}$ ) $(72.7 \%)$ in bacterial meningitis compared to the nonbacterial meningitis group. ALL patients with TBM had greater than $90 \%$ lymphocytes in CSF. CSF glucose concentration is decreased $<45 \mathrm{mg} / \mathrm{dl}$ in $72.7 \%$ of patients with bacterial meningitis and significantly above $45 \mathrm{mg} / \mathrm{dl}$ in all pateins of aseptic meningitis. Most of the cells in CSF in TBM are lymphocytes and CSF lymphocytosis greater than $50 \%$ has been reported in $80 \%$ to $83 \%$ of the patients. ${ }^{(11)}$

CSF glucose is typically normal in aseptic meningitis, although it may be decreased in cases due to enteroviruses, HSV-2, and VZV meningitis.[12] In our study Low CSF glucose and elevated protein are other characteristic abnormalities seen in TBM. In our study Low CSF glucose and elevated protein are other characteristic abnormalities seen in TBM. Berengufer et al have reported low CSF glucose in $89 \%$ of their patients.(13) Tandon et al have reviewed large series of publications and reported the incidence of low CSF glucose as varying from $50 \%$ to $95 \%$ patients.(14)

In our study only $6(12 \%)$ specimens yielded a positive culture of $M$. tuberculosis. The isolation of organisms from gastric aspirates for diagnosis of tuberculosis is low yield in pediatric practice.(18)

Newer diagnostic techniques have been introduced as CSF ADA levels for TBM. In our study CSF ADA was found to be $>5 \mathrm{IU} / \mathrm{L}$ in $96 \%$ of TBM cases. A study done by Mishra et al showed CSF ADA level in TBM cases had significant correlation with CSF cell count $(\mathrm{P}<0.01)$, lymphocyte percentage $(\mathrm{P}<0.02)$ and protein concentration $(\mathrm{P}<0.02)$. Thus, the CSF ADA activity assay was found to be a simple, useful and rapid diagnostic test for the early recognition of TBM in children.(19)

Abnormalities reported on CT scan done are hydrocephalus, infarcts, basal enhancement, and cerebral oedema. Neurological deficit were seen in 30\% of our cases. Neurologic disabilities ranging from mild to severe are reported in $10 \%$ to $50 \%$ of children who survived the infection.(20,21) Normal study is reported in up to $20 \%$ of the cases, ${ }^{(22)}$ whereas $29 \%$ of our cases had normal CT scan.

CONCLUSIONS: CSF parameters help to diagnose and differentiate various types of meningitis. CSF ADA is a simple, easy and rapid diagnostic test for early diagnosis of TBM.

Early detection and prompt therapy are the most important factors in prognosis of meningitis. 


\section{REFERENCES:}

1. K. S. Adriani, D. van de Beek, M. C. Brouwer, L. Spanjaard, and J. de Gans, "Community-acquired recurrent bacterial meningitis in adults," Clinical Infectious Diseases, vol. 45, no. 5, pp. e46-e51, 2007.

2. H. F. M. Farag, M. M. Abdel-Fattah, and A. M. Youssri, "Epidemiological, clinical and prognostic profile of acute bacterial meningitis among children in Alexandria, Egypt, " Indian Journal of Medical Microbiology, vol. 23, no. 2, pp. 95-101, 2005.

3. Blumberg HM, Burman WJ, Chaisson RE, et al. Treatment of Tuberculosis: American Thoracic Society, CDC, and Infectious Diseases Society of America. AM J Respir Crit Care Med. 2003; 167: 603-662.

4. Parthasarathy A, Narmada R, Krishnamoorthy, K. A. Tuberculosis in BCG vaccinated children. Indian Pediatr; 1982, 19, 785.

5. Gheorghin M. The present and future role of B. C. G. vaccine in tuberculosis control; Biologicals; 1990, 18, 135.

6. Filho W. V. , de Castilh E. A. , Rodngues, L. C. , Huttly SRA. Effectiveness of B. C. G. Vaccination against tuberculous meningitis; a case control study in Sao Paulo, Brazil. Bull World Health; 1990, 68, 69.

7. Kakrani, V. A. and Pratinidhi A. K. A study of childhood tuberculosis, hid. J. Tub; 1992, 39, 177.

8. Chandra P. Tuberculosis in B. C. G. vaccinated and unvaccinated children. Indian Pediatr; 1975, 12.

9. Williams EJ, Thorson S, Maskey M, Mahat S, Hamaluba M, Dongol S et al. Hospital-based surveillance of invasive Pneumococcal disease among young children in urban Nepal. Cl Infect Dis. 2009; 48: S114-22.

10. Gupta S, Chopra K. Tuberculous meningitis in children. Ind. J. Tub, 1981, 28, 3.

11. L. U. Gerdes, P. E. Jørgensen, E. Nexø, and P. Wang, “C-reactive protein and bacterial meningitis: a meta-analysis, " Scandinavian Journal of Clinical \& Laboratory Investigation, vol. 58, no. 5, pp. 383-394, 1998.

12. H. Peltola, "Burden of meningitis and other severe bacterial infections of children in Africa: implications for prevention," Clinical Infectious Diseases, vol. 32, no. 1, pp. 64-75, 2001.

13. Berengufer J, Moreno S, Laguna F, et al. Tuberculous meningitis in patients infected with the human immunodeficiency virus. N Engl J Med. 1992; 326(10): 668-672.

14. Tandon PN, Bhargava S, Gupta AK. Tuberculous meningitis-a CT study. Br J Radiol. 1982; 55 (651): 189-196.

15. K. L. Roos, “Cerebrospinal fluid, " in Principles of Neurologic Infectious Diseases, K. L. Roos, Ed., chapter 1, pp. 1-12, McGraw-Hill, 2003.

16. M. A. Dery and R. Hasbun, "Changing epidemiology of bacterial meningitis," Current Infectious Disease Reports, vol. 9, no. 4, pp. 301-307, 2007.

17. R. Mani, S. Pradhan, S. Nagarathna, R. Wasiulla, and A. Chandramuki, "Bacteriological profile of community acquired acute bacterial meningitis: a ten-year retrospective study in a tertiary neurocare centre in South India, ” Indian Journal of Medical Microbiology, vol. 25, no. 2, pp. 108-114, 2007.

18. Kibel M. A., Hussey G. Problems in the diagnosis of childhood tuberculosis. S. Afr. Med J, 1990.

19. Mishra OP, Loiwal V, Ali Z, Nath G, Chandra L. J Trop Pediatr. 1996 Jun; 42(3): 129-32. 


\section{ORIGINAL ARTICLE}

20. Lober J. Long-term follow-up of 100 children who recovered from tuberculous meningitis. Pediatrics. 1961; 28: 778-791.

21. Kingsley DP, Hendrickse WA, Kendall BE, et al. Tuberculous meningitis: role of CT in management and prognosis. J Neurol Neurosurg Psychiatry. 1987; 50(1): 30-36.

22. National Guidelines on diagnosis and treatment of Pediatric Tuberculosis, January-February 2012.

\section{AUTHORS:}

1. Nisha Pandey

2. Ajay Pratap

\section{PARTICULARS OF CONTRIBUTORS:}

1. Assistant Professor, Department of Paediatrics, Rohilkhand Medical College and Hospital, Bareilly, U. P.

2. Associate Professor, Department of Paediatrics, Rohilkhand Medical College and Hospital, Bareilly, U. P.

FINANCIAL OR OTHER

COMPETING INTERESTS: None
NAME ADDRESS EMAIL ID OF THE

\section{CORRESPONDING AUTHOR:}

Ajay Pratap,

Associate Professor,

Department of Paediatrics,

Rohilkhand Medical College and Hospital,

Bareilly, U. P. India.

E-mail: drajay_pratap@yahoo.com

Date of Submission: 16/05/2015.

Date of Peer Review: 17/05/2015.

Date of Acceptance: 27/05/2015.

Date of Publishing: 03/06/2015. 